\title{
Nafarelin Acetate
}

National Cancer Institute

\section{Source}

National Cancer Institute. Nafarelin Acetate. NCI Thesaurus. Code C1144.

The acetate salt form of nafarelin, a modified synthetic porcine luteinizing hormone (LH)releasing hormone peptide analog, with gonadotropin-releasing hormone (GnRH) agonist activity. Upon nasal inhalation, nafarelin acetate binds to the GnRH receptor. This initially results in the release of the gonadotropins, follicle-stimulating hormone (FSH) and $\mathrm{LH}$, from the pituitary gland; however, prolong ed stimulation of the GnRH receptor desensitizes the receptor, which leads to decreased secretion of FSH and LH. In females, the inhibition of gonadotropin secretion causes hypogonadotropic hypogonadism leading to decreased production of estrogen and progesterone and anovulation. In males, the inhibition of LH secretion prevents the production and release of testosterone from Leydig cells in the testes and causes a significant decline in testosterone production that is near the levels seen following castration. 